\title{
GROWTH AND PRODUCTION OF Vigna unguiculata L. SUBMITTED TO ORGANIC FERTILIZATION WITH EARTHWORM HUMUS
}

Toni Halan da Silva Irineu ${ }^{1}$, Josimar Nogueira da Silva ${ }^{1}$, Mario Leno Martins Véras ${ }^{2}$, Paulo Cássio Alves Linhares ${ }^{1}$, Joselma Nogueira da Silva ${ }^{3}$, Janailson Pereira de Figueredo ${ }^{2}$, Ériton Eriberto Martins Dantas $^{3} \&$ Raimundo Andrade ${ }^{3}$

\footnotetext{
${ }^{1}$ Universidade Federal Rural do Semiárido. E-mail: tonnyirineupb@hotmail.com; josimar2160@hotmail.com; paulo_linhares2011@ hotmail.com

${ }^{2}$ Universidade Federal da Paraíba. E-mail: mario.deus1992@bol.com.br; janailsondfigueredo@hotmail.com

${ }^{3}$ Universidade Estadual da Paraíba. E-mail: joselma.nogueira@hotmail.com; eritoneriberto@ outlook.com;

raimundoandrade@uepb.edu.br
}

\section{ABSTRACT}

Organic fertilization is a potential agroecological practice for the optimization of the cowpea production chain. The objective of this work was to evaluate the amounts of earthworm humus incorporated into the soil and the liquid humus via leaves in cowpea plants. The experiment was carried ou tin 2012, using the "BRS pujante" variety cultivated in Fluvic Neossol. The experimental design was in randomized blocks, in a factorial scheme $5 \times 2$, and 4 replications, totaling 40 plots. It was studied five amounts of earthworm humus: $\left(0.0 ; 2.0 ; 3.0 ; 4.0\right.$; and $5.0 \mathrm{~kg} \mathrm{~m}^{-1}$ per line) and liquid humus: ( $\mathrm{H}_{1}=$ presence and $\mathrm{H}_{0}=$ absence). The amount of $5 \mathrm{~kg} \mathrm{~m}^{-1}$ of earthworm humus per line provided higher values for grain mass, number of grains and of pods, whereas the mass of 100 grains was influenced by the lower amount of humus. There was no difference between application of liquid humus $\left(\mathrm{H}_{1}\right)$ to any of the variables.

Keywords: Cowpea, Lumbricus rubellus, agroecology, semiarid

\section{CRESCIMENTO E PRODUÇÃO DE Vigna unguiculata L. SUBMETIDO À ADUBAÇÃO ORGÂNICA COM HÚMUS DE MINHOCA}

\section{RESUMO}

Adubação orgânica é uma prática agroecológica em potencial para otimização da cadeia produtiva do feijoeiro. Objetivou-se com este trabalho avaliar quantidades de húmus de minhoca incorporadas ao solo e de húmus líquido via foliar em plantas de feijão-caupi. O experimento foi 
conduzido em 2012, utilizando a variedade "BRS pujante" cultivada em Neossolo Flúvico. O delineamento utilizado foi em blocos casualizados, num esquema fatorial 5 x 2, e 4 repetições, totalizando 40 parcelas. Estudaram-se cinco quantidades de húmus de minhoca: $(0,0 ; 2,0 ; 3,0 ; 4,0$ e 5,0 $\mathrm{kgm}^{-1}$ por linha) e de húmus líquido: ( $\mathrm{H}_{1}=$ presença e $\mathrm{H}_{0}=$ ausência). A quantidade de $5 \mathrm{~kg} \mathrm{~m}^{-1}$ por linha de húmus de minhoca proporcionou maiores valores para massa de grãos, número de grãos e de vagens, já a massa de 100 grãos foi influenciada pela menor quantidade de húmus. Não houve diferença entre aplicação do húmus líquido $\left(\mathrm{H}_{1}\right)$ para nenhuma das variáveis.

Palavras-chave: Caupi, Lumbricus rubellus, agroecologia, semiárido

\section{INTRODUCTION}

The cowpea (Vigna unguiculata (L.) Walp) is cultivated in several arid and semi-arid regions. This crop presents good rusticity, tolerance to high temperatures, drought, and good conditions for adaptation and expansion of these exploited areas. It is considered a major food to these populations (COELHO et al., 2013). This legume has high protein content, being its seeds a source of amino acids, thiamine, niacin, and also dietary fibers. Thus, this is a good option to improve life quality, as a low cost food (FONSECA et al., 2010).

The cowpea is very adapted to the different types of organic fertilizers. Given that, this system of organic production presents itself as a potential practice to optimize the production chain of vigna cowpea in the semiarid (PEREIRA et al, 2013b). In turn, cowpea is a crop that requires few soil fertility (ANDRADE JÚNIOR et al, 2007), as organic fertilization is widely studied as a form of nutrition for vegetables, with a reduction in the application of chemical fertilizers, and consequently, greater conservation of natural resources (PEREIRA et al., 2013a).

Numerous products of organic origin can promote greater soil fertility and increase crop yields. Among these fertilizers, there are earthworm humus, which is a substance extremely rich in decomposed organic matter (RODRIGUES et al., 2012). It is an organic fertilizer of excellent quality, which besides increasing soil fertility providing nutrients such as $\mathrm{N}, \mathrm{P}, \mathrm{K}, \mathrm{Ca}$, and $\mathrm{Mg}$, it is also very important for maintenance and improvement of the physical attributes of the soil, such as: aeration, water infiltration and retention, humidity maintenance, and soil structure improvement.

Earthworm humus can be used both in liquid form and in solid form. For the production of liquid humus, the solid earthworm humus is mixed with water and let resting for 24 hours, then the nutrients 
present in the humus can be released into the water. This solution will contain mineral nutrients and organic acids that provide the growth and development of plants (ARTEAGA et al., 2007). Its use benefits cowpea, increasing its productivity and yield (CAVALCANTE et al., 2009), because when these fertilizers are applied to the leaf in liquid form, their absorption occurs more rapidly and these nutrients translocate to all vegetative parts of the plant.

Considering the scarcity of studies in the literature regarding organic fertilization with earthworm humus in semi-arid conditions and the growing need for sustainable and economically viable practices in agriculture, the objective of this work was to evaluate amounts of earthworm humus embedded in the soil and the liquid humus via leaf in cowpea plants.

\section{MATERIAL AND METHODS}

The research was carried out under field conditions at the State School of Elementary and Middle Education Nossa Senhora da Conceição, in the municipality of Belém de Brejo do Cruz. This municipality is located in the semi-arid region of Northeastern Brazil, in the Northwest of the State of Paraíba, whose geographical coordinates are: 6²8'12 "S, 37²0'32" W of Greenwich having an altitude of $176 \mathrm{~m}$. The climate of the municipality, according to the Köppen classification, is of the type BSWh ', that is: dry, very hot type of steppe, with rainy season in the summer, and with the coldest temperature of the month superior to $18^{\circ} \mathrm{C}$.

Soil analysis was performed at $0-20 \mathrm{~cm}$ depth, classified as Fluvic Neossol, according to the Brazilian Soil Classification System (SBCS) (SANTOS et al., 2013), presenting the following characteristics: $\mathrm{pH}\left(\mathrm{H}_{2} \mathrm{O}\right)=6.00 ; \mathrm{Ca}^{+2}=2.34\left(\mathrm{cmol}_{\mathrm{c}} \mathrm{dm}^{-3}\right) ; \mathrm{Mg}^{+2}=2.41\left(\mathrm{cmol}_{\mathrm{c}} \mathrm{dm}^{-3}\right) ; \mathrm{Na}^{+}=0.02$ $\left(\mathrm{cmol}_{\mathrm{c}} \mathrm{dm}^{-3}\right) ; \mathrm{K}^{+}=0.33\left(\mathrm{mg} \mathrm{dm}{ }^{-3}\right) ; \mathrm{H}=0.69\left(\mathrm{cmol}_{\mathrm{c}} \mathrm{dm}^{-3}\right) ; \mathrm{Al}^{+3}=0.00\left(\mathrm{cmol}_{\mathrm{c}} \mathrm{dm}^{-3}\right) ; \mathrm{CTC}=5.79$ $\left(\mathrm{cmol}_{\mathrm{c}} \mathrm{dm}^{-3}\right) ; \mathrm{SB}=88(\%) ;$ C.O. $=4.7(\%) ; \mathrm{M} . \mathrm{O} .=8.1(\%) ; \mathrm{N}^{+}=0.4\left(\mathrm{~g} \mathrm{~kg}^{-1}\right) ;$ assimilable phosphoryl = $1.83(\mathrm{mg} / 100)$; sand $=640$; silt $=206$; clay $=154\left(\mathrm{~g} \mathrm{~kg}^{-1}\right)$; overall density $=1.54$; particle density $=$ $2.68\left(\mathrm{~g} \mathrm{~cm}^{-3}\right)$; total porosity $=42.54(\%)$; field capacity $=146.9$; permanent wilting point $=76.60$; available water $=70.3\left(\mathrm{~g} \mathrm{~kg}^{-1}\right)$; and textural class = sandy loam.

The experimental design was a randomized complete block design, with 10 treatments, in a 5 x 2 factorial scheme with four replications, totaling 40 experimental plots. The effects of five amounts of California red (Lumbricus rubellus) earthworm humus were studied: $\left(\mathrm{A}_{1}=0.0, \mathrm{~A}_{2}=2.0, \mathrm{~A}_{3}=3.0, \mathrm{~A}_{4}=\right.$ 4.0 , and $\mathrm{A}_{5}=5.0 \mathrm{~kg} \mathrm{~m}^{-1}$ per line $)$, and two sources of liquid humus with $\left(\mathrm{H}_{1}=\right.$ presence $)$ and without ( $\mathrm{H}_{0}=$ absence $)$. 
The soil preparation consisted of cleaning the experimental area; it was performed manually with the aid of a hoe, then the experimental plots were delineated and the foundation fertilization was carried out with the said amounts of earthworm humus placed in the planting line and posteriorly incorporated into the soil. Two days after fertilization of the foundation, the planting was manually done in holes with seeds of cowpea of the "BRS pujante" variety, on March 24th, 2012, placing three seeds per hole at the spacing of $1.0 \times 0.50 \mathrm{~m}$, totaling a population density of 20,000 plants/hectare.

A thinning of the plants was carried out eight days after sowing (DAS), leaving only one plant per hole. Manual weeding was carried out whenever necessary, minimizing competition for water and nutrients.

The liquid humus was obtained by dilution in water in a ratio of 4:1, consisting of 20 liters of water to $5 \mathrm{~kg}$ of earthworm humus, being standardized and placed in rest for 24 hours for the proper application in the treatments applied via leaf with costal pump aid. The applications were carried out in the interval of eight days between each application, with the beginning of the first application 30 days after sowing. Four applications of the liquid humus were made, and the applications ceased when the plants reached full flowering.

The chemical analysis of earthworm humus was determined in the Irrigation and Salinity Laboratory (LIS) of the Center of Technology and Natural Resources of the Federal University of Campina Grande - UFCG, and it presented the following characteristics: $\mathrm{pH}_{2} \mathrm{O}(1: 2.5)=7.38$, electrical conductivity $=2.11 \mathrm{dS} / \mathrm{m}$; calcium $=35.40 \mathrm{meq} / 100 \mathrm{~g}$ soil; magnesium $=19.32 \mathrm{meq} / 100 \mathrm{~g}$ soil; sodium $=1.82 \mathrm{meq} / 100 \mathrm{~g}$ soil; potassium $=1.41 \mathrm{meq} / 100 \mathrm{~g}$ soil $; \mathrm{S}=57.95 \mathrm{meq} / 100 \mathrm{~g}$ soil; hydrogen $=0.00 \mathrm{meq} / 100 \mathrm{~g}$ soil); aluminum $=0.00 \mathrm{meq} / 100 \mathrm{~g}$ soil; $\mathrm{T}=57.95 \mathrm{meq} / 100 \mathrm{~g}$ of soil; qualitative calcium carbonate $=$ present and assimilable phosphorus $=55.14 \mathrm{meq} / 100 \mathrm{~g}$ of soil.

The irrigation system adopted was located by the Santeno II (Leisure) tape method with water supplied through a reservoir available at the school itself, pumped through a single-phase $1.0 \mathrm{cv}$ pump. Irrigations were carried out with daily irrigation, divided in two applications (morning and afternoon), providing a water slide of approximately $8.0 \mathrm{~mm} \mathrm{day}^{-1}$ with the purpose of favoring the microbial activity of the soil. The water used in the irrigation had a pH of 7.53, electrical conductivity of 0.8 (dS $\mathrm{m}^{-1}$ ), being classified, according to Richards (1954), as $\mathrm{C}_{3} \mathrm{C}_{1}$.

The variables analyzed were: grain mass per plant, number of grains per plant, mass of 100 grains, number of pods per plant, main branch length, and stem diameter. The statistical analyses were carried out with the aid of the SISVAR 5.0 computational program. The data were analyzed and 
interpreted from analysis of variance (F test) and by average comparison by the Tukey test, according to Ferreira (2011), at the $1 \%$ and $5 \%$ significance levels.

\section{RESULTS AND DISCUSSION}

There were no interactions between the amounts of earthworm humus incorporated into the soil and the liquid humus applied via leaf to the variables: grain mass per plant, number of grains per plant, mass of 100 seeds, number of pods per plant, main branch length, and stem diameter (Table 1). However, when analyzing the isolated factors (amounts of earthworm humus and liquid humus), we can verify that the grain mass per plant, number of grains per plant, mass of 100 seeds, and number of pods per plant were influenced only by amounts of earthworm humus.

Table 1. Summary of analysis of variance for grain mass per plant (GMP), number of grains per plant (NGP), mass of 100 seeds (M100S), number of pods per plant (NPP), main branch length (MBL), and stem diameter (SD), of cowpea plants (Vigna unguiculata L.) as a function of amounts of earthworm humus and liquid humus, Belém do Brejo do Cruz, PB, 2012.

\begin{tabular}{lccccccc}
\hline \multirow{2}{*}{ SOURCE VARIATION } & \multirow{2}{*}{ GL } & \multicolumn{7}{c}{ AVERAGE SQUARES } \\
\cline { 3 - 7 } & & GMP & NGP & M100S & NPP & MBL & SD \\
\hline Amounts of humus (A) & 4 & $145.60^{* *}$ & $649.41^{* *}$ & $16.93^{* *}$ & $1521.28^{* *}$ & $0.392^{\mathrm{ns}}$ & $4.47^{\mathrm{ns}}$ \\
$1^{\text {o }}$ degree components & 1 & $529.56^{* *}$ & $2377.84^{* *}$ & $35,68^{* *}$ & $2.92^{*}$ & $0.010^{\mathrm{ns}}$ & $7.84^{\mathrm{ns}}$ \\
$2^{\mathrm{o}}$ degree components & 1 & $19.05^{\mathrm{ns}}$ & $148.22^{\mathrm{ns}}$ & $7.43^{\mathrm{ns}}$ & $0.56^{\mathrm{ns}}$ & $0.002^{\mathrm{ns}}$ & $9.65^{\mathrm{ns}}$ \\
Regression deviation & 2 & 169.16 & 35.79 & 12.31 & 3.08 & 0.778 & 0.18 \\
Liquid humus(H) & 1 & $25.60^{\mathrm{ns}}$ & $133.22^{\mathrm{ns}}$ & $0.02^{\mathrm{ns}}$ & $270.40^{\mathrm{ns}}$ & $0.770^{\mathrm{ns}}$ & $0.04^{\mathrm{ns}}$ \\
Interaction (A x H) & 4 & $23.85^{\mathrm{ns}}$ & $96.41^{\mathrm{ns}}$ & $2.46^{\mathrm{ns}}$ & $100.08^{\mathrm{ns}}$ & $0.181^{\mathrm{ns}}$ & $1.14^{\mathrm{ns}}$ \\
Residual & 30 & 5.83 & 587.04 & 2.15 & 158.08 & 0.413 & 2.42 \\
CV (\%) & & 5.78 & 10.06 & 4.18 & 16.72 & 28.49 & 15.65 \\
\hline
\end{tabular}

GL: Degree of freedom, ${ }^{* *}$ and $*$ significant at 1 and 5\% of probability, respectively, and ${ }^{\mathrm{ns}}$ not significant by the $\mathrm{F}$ test.

The evolution of grain mass per plant presented an increasing linear behavior (Figure 1A). It was verified that when the amount of humus was increased there was an increase in mass of grains per plant, where the highest amount applied was obtained the maximum value $49.28 \mathrm{~g}$, when compared to the control amount of $5.0 \mathrm{~kg} \mathrm{~m}^{-1}$ per line, an increase of $43.46 \%$ was noticed respectively. The results corroborate those found by Cavalcante et al. (2009), studying the mass of grains per plant, where they observed an increase with the increment up to the estimated dosage of $89.3 \mathrm{ml} / \mathrm{plant} / \mathrm{time}$ of unfertilized biofertilizer, providing a maximum weight of $48 \mathrm{~g}$.

This behavior observed in the grain mass per plant is related to the fact that this crop responds very well to fertilization with earthworm humus and other organic composts, improving the physical, 
chemical and biological characteristics of the soil also. Galbiatti et al. (2011) studying the cowpea productivity observed that the treatments that received the biodigester effluent based on bovine manure presented the best productivity.

Probably this increase in grain mass per plant has occurred due to the fact that earthworm humus was already supplied in a form of aerobic decomposition by earthworms that potentiate the action of microorganisms in the soil because it is very rich in macro and micronutrients.

It is observed (Figure 1B) that the number of grains per plant was influenced by the amounts of earthworm humus, adjusting itself to an increasing linear model, evidencing an increase of 134.92 of number of grains per plant at each amount of humus applied, where the highest amount of humus used provided a maximum value of 246 , in the number of grains per plant, observing an increase rate of $82.22 \%$, respectively, when related to the control.
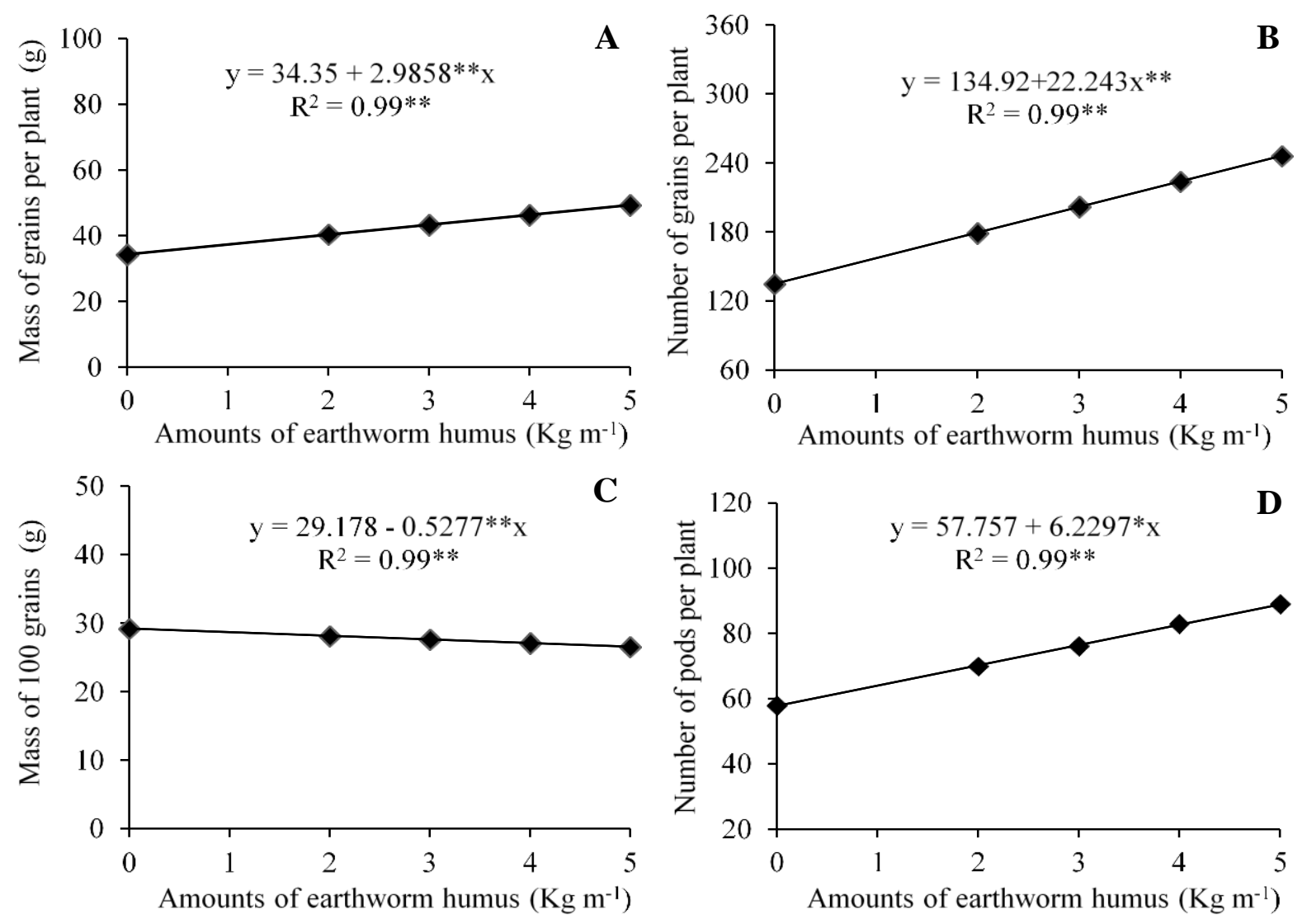

Figure 1. Mass of grains per plant (A), number of grains per plant (B), mass of 100 grains (C), and number of pods per plant (D), of cowpea plants (Vigna unguiculata L.) as a function of amounts of earthworm humus, Belém do Brejo do Cruz, PB, 2012. 
This result can be attributed to better plant nutrition, that according to Longo (1995), earthworm humus is on average $70 \%$ richer in nutrients than conventional humus, where the $\mathrm{N}$ content is almost five times higher, while $\mathrm{P}$ is seven, $\mathrm{K}$ is eleven and $\mathrm{Mg}$ is three times greater. Thus, these nutrients content in the soil expand the root system of the plant, thus a better absorption of these nutrients occur, and in turn also occurs a greater translocation of these to the vegetative part of the plant, leaving it more nourished and with greater productive capacity.

For the mass of 100 seeds, a significant decreasing linear model was observed (Figure 1C). It was observed that the amount of earthworm humus increased in the "BRS pujante" cowpea plants. There was a reduction of the mass of 100 seeds, observing that the control obtained the highest value (29.18 g) while the highest amount of humus of earthworm provided lower value $(26.54 \mathrm{~g})$. The results obtained in this variable differ from those found by Gerlach et al. (2013). When evaluating the organic and mineral fertilization in the development and productivity of the cultivars of precocious cowpea (type I), Juriti (type II), and Perola (type III), they found better results with organic fertilization, however, inferior to those results found in the present research.

This behavior may be possibly attributed due to the fact of the availability of the high level of mineralized fertilizer by the microorganisms in short time for the plants to assimilate large amounts of nutrients. However, successive applications of organic compounds into the soil can cause negative effects in both soil and plants (GALBIATTI et al., 2011; FIGUEIREDO et al., 2012; PEREIRA et al., 2013a).

There was a linear increase in the number of pods per plant, evidencing an increase of 57.757, per $\mathrm{kg} \mathrm{m}^{-1}$ per line of earthworm humus applied to the soil, with a maximum value of 89 in the amount of 5 $\mathrm{kg} \mathrm{m}^{-1}$ per line of earthworm humus, with an increase of $53.44 \%$ when compared to the control (Figure 1D). These results are in agreement with those of Pereira et al. (2013a) when evaluating the yield of the cowpea vigna founding superiority in the number of pods per plant with the use of earthworm humus.

This increasing behavior in the number of pods per plant with the applications of humus can be attributed to the composition of earthworm humus, where it constitutes an excellent source of nutrients, besides changing the physical and chemical characteristics of the soil, promoting nutrient supply to the cowpea (OLIVEIRA et al., 2001).

No significant difference was observed in the length of the main branch, with the mean values of the smallest amount being greater than $2.23 ; 2.25 ; 2.26 ; 2.27$; and $2.28(\mathrm{~m})$ respectively, resulting in an 
increase of $2.24 \%, 1.33 \%, 0.88 \%$, and $0.44 \%$ in the amount of humus of $\mathrm{A}_{5}\left(5.0 \mathrm{~kg} \mathrm{~m}^{-1}\right.$ per line $)$ in relation to the amounts $\left(0.0,2.0,3.0\right.$ and $4.0 \mathrm{~kg} \mathrm{~m}^{-1}$ per line), according to the Table 2.

Table 2. Length of main branch (LMB) and stem diameter (SD), of cowpea plants (Vigna unguiculata L.) as a function of amounts of earthworm humus, Belém do Brejo do Cruz, PB, 2012.

\begin{tabular}{ccc}
\hline \multirow{2}{*}{ Amounts of humus } & \multicolumn{3}{c}{ Analyzed variables } \\
\cline { 2 - 3 } & LMB $(\mathrm{m})$ & SD $(\mathrm{mm})$ \\
\hline $\mathrm{A}_{1}$ & $2.23 \mathrm{a}$ & $8.69 \mathrm{a}$ \\
$\mathrm{A}_{2}$ & $2.25 \mathrm{a}$ & $8.94 \mathrm{a}$ \\
$\mathrm{A}_{3}$ & $2.26 \mathrm{a}$ & $9.07 \mathrm{a}$ \\
$\mathrm{A}_{4}$ & $2.27 \mathrm{a}$ & $9.20 \mathrm{a}$ \\
$\mathrm{A}_{5}$ & $2.28 \mathrm{a}$ & $9.33 \mathrm{a}$ \\
\hline
\end{tabular}

*Means followed by the same lowercase letter in the column do not differ statistically by the Tukey test at 5\% probability.

The results found corroborate with those obtained by Pereira et al. (2013b), who observed nonsignificant effects on main branch length by studying the growth and yield of vigna cowpea submitted to organic fertilization with bovine manure, goat manure and earthworm humus. Differentiated behaviors were observed by Nascimento et al. (2004) studying the effect of variation of available water levels on the growth and production of cowpea cv. IPA 206 where they were submitted to the regression analysis, observing quadratic effect.

Regarding the stem diameter, no significant difference was observed, with a change from 8.69 to $9.33 \mathrm{~mm}$ in the stem diameter between the lowest and the highest amount of earthworm humus with an increase of $7.36 \%$, in relation to the amount $\left(\mathrm{A}_{5}\right)$, from $\mathrm{kg} \mathrm{m}^{-1}$ per line to $\mathrm{A}_{1}\left(0.0 \mathrm{~kg} \mathrm{~m}^{-1}\right.$ per line).

According to Santana et al. (2012), this slight increase in the stem diameter of the plant occurred possibly due to the addition of organic matter into the soil, resulting in beneficial effects, such as the improvement in the biological, physical and chemical properties of the soil, thus increasing the supply of nutrients to the plants.

The results obtained in the present research were superior to those found by Giomo et al. (2001), that when studying different dosages and concentrations of biofertilizers they found diameters ranging from 7.9 to $8.8 \mathrm{~mm}$ in cowpea plants. On the other hand, the results found resemble those obtained by Santana et al. (2012) and Pereira et al. (2013b) that when studying the growth and yield of Vigna cowpea submitted to organic fertilization with bovine manure, goats manure, and earthworm humus also did not observe significant difference for this characteristic. 
As for the liquid humus of earthworm applied to "BRS pujante" cowpea plants, it can be observed that the analyzed variables were not statistically affected by the application of liquid humus, according to Table 3 .

Table 3. Grain mass per plant (MGP), number of grains per plant (NGP), mass of 100 seeds (M100S), main branch length (CRP) and stem diameter (DC), of cowpea plants (Vigna unguiculata L.) as a function of presence $\left(\mathrm{H}_{1}\right)$ and absence $\left(\mathrm{H}_{0}\right)$ of liquid humus, Belém do Brejo do Cruz, PB, 2012.

\begin{tabular}{ccccccc}
\hline \multirow{2}{*}{ Liquid humus } & \multicolumn{7}{c}{ Analyzed variables } \\
\cline { 2 - 6 } & GMP $(\mathrm{g})$ & NGP & M100S $(\mathrm{g})$ & NPP & MBL $(\mathrm{m})$ & SC $(\mathrm{mm})$ \\
\hline $\mathrm{H}_{1}$ & $43.56 \mathrm{a}$ & $198 \mathrm{a}$ & $28.15 \mathrm{a}$ & $78 \mathrm{a}$ & $2.39 \mathrm{a}$ & $9.05 \mathrm{a}$ \\
$\mathrm{H}_{0}$ & $41.86 \mathrm{a}$ & $197 \mathrm{a}$ & $27.25 \mathrm{a}$ & $73 \mathrm{a}$ & $2.17 \mathrm{a}$ & $9.04 \mathrm{a}$ \\
\hline
\end{tabular}

*Means followed by the same lowercase letter in the column do not differ statistically by the Tukey test at $5 \%$ probability.

For the analyzed characteristics of the cowpea grain mass per plant, number of grains per plant, mass of 100 seeds, number of pods per plant, main branch length, and stem diameter, submitted to the application of liquid humus with $\left(\mathrm{H}_{1}\right)$ and without $\left(\mathrm{H}_{0}\right)$, although they did not behave significantly. There was an increase in treatments with liquid humus $\left(\mathrm{H}_{1}\right)$ of $4.06 \%, 0.50 \%, 3.30 \%, 6.84 \%, 0.13 \%$, and $0.11 \%$, in relation to the treatments without applications of liquid humus $\left(\mathrm{H}_{0}\right)$, respectively.

The data found in the present study corroborate with those found by Linhares et al. (2014) who, when studying the amount of humus in the cowpea grown organically fertilized in soil and climate conditions in Catolé do Rocha, observed similar statistical effects for the stem diameter. In the same way, Beltrão Júnior et al. (2012), when evaluating the yield of cowpea fertilized with different dosages of organic biofertilizer produced through the accelerated biodegradation of coconut waste in the municipality of Trairí, CE, they found significant differences for the characteristics analyzed. According to Silva et al. (2011), organic fertilization not only increases productivity, but also produces plants with better qualitative characteristics.

According to Figueiredo et al. (2012), very high dosages of organic fertilizers can become harmful to the crops, which will depend on their chemical composition, rate of mineralization and nitrogen content.

\section{CONCLUSIONS}


The amount of $5 \mathrm{~kg} \mathrm{~m}^{-1}$ per line of earthworm humus provides higher values for grain mass per plant, number of grains per plant, and number of pods per plant, except for the mass of 100 grains which was influenced by the least amount of earthworm humus.

The application of liquid humus $\left(\mathrm{H}_{1}\right)$ does not influence the grain mass per plant, number of grains per plant, mass of 100 seeds, number of pods per plant, main branch length, and stem diameter of "BRS pujante" cowpea plants.

\section{REFERENCES}

ANDRADE JÚNIOR, A. S.; BARROS, A. H. C.; SILVA, C. O.; FREIRE FLHO, F. R. 2007. Zoneamento de risco climático para a cultura do feijão-caupi no Estado do Ceará. Revista Ciência Agronômica, Fortaleza, v. 38, n. 01, p. 109-117.

ARTEAGA, M; GARCÉS, N.; NOVO, R.; GURIDI, F.; PINO, J. A.; COSTA, M.; PASOS, M.; BESÚ, D. 2007. Influencia de la aplicación foliar del bioestimulante Liplant sobre algunos indicadores biológicos delsuelo. Revista de Protección Vegetal, La Habana, v. 22, n. 2, p. 110-117.

BELTRÃO JÚNIOR, J. A.; CRUZ, J. S.; SOUSA, E. C.; SILVA, L. A. 2012. Rendimento do feijãocaupi adubado com diferentes doses de biofertlizante orgânico produzido através da biodegradação acelerada de resíduos do coqueiro no município de Trairí-CE. Irriga, Botucatu, p. 423-437, Edição Especial.

CAVAlCANTE, S. N.; DUTRA, K. O. G.; MEDEIROS, R.; LIMA, S. V.; SANTOS, J. G. R.; ANDRADE, R.; MESQUITA, E. F. 2009. Comportamento da produção do feijoeiro macassar (Vigna unguiculata L. Walp) em função de diferentes dosagens e concentrações de biofertilizante. Revista de Biologia e Ciências da Terra, Campina Grande, supl. esp., n.1, p. 10-14.

COELHO, J. B. M.; BARROS, M. F. C.; BEZERRA NETO, E.; CORREA, M. M. 2013. Comportamento hídrico e crescimento do feijão vigna cultivado em solos salinizados. Revista Brasileira de Engenharia Agrícola e Ambiental, Campina Grande, v.17, n.4, p.379-385.

FERREIRA, D. F. 2011. Sisvar: a computerstatisticalanlysis system. Ciência e Agrotecnologia, Lavras, v. 35, n. 6, p. 1039-1042.

FIGUEIREDO, C. C.; RAMOS, M. L. G.; McMANUS, C. M.; MENEZES, A. M. 2012. Mineralização de esterco de ovinos e sua influência na produção de alface. Horticultura Brasileira, Vitória da Conquista, v.30, n.1, p.175-179.

FONSECA, M. R.; FERNANDES, A. R.; SILVA, G. R.; BRASIL, E. C. 2010. Teor e acúmulo de nutrientes por plantas de feijão caupi em função do fósforo e da saturação por bases. Revista de Ciências Agrárias, Minas Gerais, v. 53, n. 2, p. 195-205.

GAlBIATTI, J. A.; SILVA, F. G.; FRANCO, C. F.; CARAMELO, A. D. 2011. Desenvolvimento do feijoeiro sob o uso de biofertilizante e adubação mineral. Engenharia Agrícola, Jaboticabal, v.31, n.1, p.167-177.

GERLACH, G. A. X.; ALF, O.; SILVA, J. C.; RODRIGUES, R. A. F.; GITTI. D. C. 2013. Aplicação de biofertilizante orgânico e mineral em feijoeiro irrigado no período de inverno. Enciclopédia Biosfera, Goiânia, v.9, n.16; p. 285-294.

GIOMO, G. S.; RAZERA, L. F.; NAKAGAWA, J. 2001. Espaçamentos para produção de sementes de guandu em semeadura tardia. Bragantia, Campinas, v. 60, n. 2, p.121-126. 
LINHARES, P. C. A., SILVA, J. N., SOUZA, J. A., SOUSA, T. P., ANDRADE, R., MARACAJÁ, P. B. 2014. Crescimento do feijão-caupi sob adubação orgânica em condições edafoclimáticas de Catolé do Rocha-PB. Informativo Técnico do Semiárido, Pombal, v. 8, n. 1, p. 90-95.

LONGO, A. D. 1995. Minhoca: de fertilizadora do solo a fonte alimentar. 4. ed. São Paulo: Ícone. 79 p. NASCIMENTO, J. T.; PEDROSA, M. B.; TAVARES SOBRINHO, J. 2004. Efeito da variação de níveis de água disponível no solo sobre o crescimento e produção de feijão caupi, vagens e grãos verdes. Horticultura Brasileira, Brasília, v. 22, n. 2, p. 174-177.

OLIVEIRA, A. P.; ESPÍNOLA, J. E.; ARAÚJO, J. S.; COSTA, C. C. 2001. Produção de raízes de cenoura cultivadas com húmus de minhoca e adubo mineral. Horticultura Brasileira, Brasília, v.19, n.1, p.77-80.

PEREIRA, R. F.; LIMA, A. S., MAIA FILHO, F. C. F.; CAVALCANTE, S. N.; SANTOS, J. G. R.; ANDRADE, R. 2013a. Produção de feijão vigna sob adubação orgânica em ambiente semiárido. Agropecuária Científica no Semiárido, Patos, v.9, n.2, p.27-32.

PEREIRA, R. F.; CAVALCANTE, S. N.; LIMA, A. S.; MAIA FILHO, F. C. F.; SANTOS, J. G. R. 2013b. Crescimento e rendimento de feijão vigna submetido à adubação orgânica. Revista Verde de Agroecologia e Desenvolvimento Sustentável, Mossoró, v. 8, n. 3, p. 91-96.

RICHARDS, L. A. 1954. Diagnosis and improvement of saline and alkaline soils.: United States Salinity Laboratory Staff. Washington 160 p. (Agriculture, 60).

RODRIGUES, T. R. D.; BROETTO, L.; OLIVEIRA, P. S. R.; RUBIO, F. 2012. Desenvolvimento da cultura do milho submetida a fertilizantes orgânicos e minerais. Biosciência Journal, Uberlândia, v.28, n.4, p. 509-514.

SANTANA, C. T. C.; SANTI, A.; DALLACORT, R.; SANTOS, M. L.; MENEZES, C. B. 2012. Desempenho de cultivares de alface americana em resposta a diferentes doses de torta de filtro. Ciência Agronômica, Fortaleza, v.43, n.1, p.22-29.

SANTOS, H. G.; JACOMINE, P. K. T.; ANJOS, L. H. C.; OLIVEIRA, V. A.; LUMBRERAS, J. F.; COELHO, M. R.; ALMEIDA, J. A.; CUNHA, T. J. F.; OLIVEIRA, J. B. 2013. Sistema brasileiro de classificação de solos. 3. ed. revisada e ampliada. Brasília, DF: Embrapa. 353 p.

SILVA, E. M. N. C. P.; FERREIRA, R. L. F.; ARAÚJO NETO S. E.; TAVELLA, L. B.; SOLINO, A. J. S. 2011. Qualidade de alface crespa cultivada em sistema orgânico, convencional e hidropônico. Horticultura Brasileira, Brasília, v.29, p.242-245. 